\title{
AN ANALYSIS OF VALUE STOCKS IN INDIAN EQUITY MARKET IN 2020
}

\author{
Dr. Chaya R \\ Assistant Professor, Department of studies and research in commerce, Karnataka State open \\ University, Mysuru, Karnataka, India
}

Sharada Devi K G

Research scholar, Department of studies and research in commerce, Karnataka State open University, Mysuru, Karnataka, India

\begin{abstract}
After a pandemic affected 2020, the Indian Equity market is on a high level of optimism to deliver positive returns. It is expected that stocks with some intrinsic value and margin of safety will perform well in 2021 as well. Brokers are advising clients to buy quality value stocks as these stocks are cheap in terms of valuations. Value stocks are available in the markets at any given point of time. One has to adopt the right process to identify stocks that are trading with some intrinsic value and showing adequate margin to safety. One of the practical ways to find value stocks is to first ascertain if the stocks are financially sound and that the fundamentals are attractive. Once the stocks with attractive fundamentals are identified, it will be interesting to note if the Trailing 12 Months (TTM) PE for the company is less than the industry PE or more than the industry average. Certain segment of the Indian population continuously investing in stocks of different sectors is expecting high returns at low risk. In doing so, of late the Indian equity investors have been contemplating if Value Investing will serve the purpose of maximizing returns or gains on their investments. The question is how does one identify value stocks and are they available in the current buoyant market scenario? There is also a need to study if value stock investing be a market-beating strategy. The concept of Value Investing is known, but not explored fully in Indian context. It is necessary to explore the prospects of value investing in Indian Scenario, especially when the capital market is hit by the pandemic. In the Indian context, such analysis is not comprehensive to help the Indian investors. The objectives of the study were to (1) identify value stocks in 2020, (2) Calculate the P/E ratio of selected stocks and compare it with industry P/E (3) to calculate the YTD of the selected stocks.

Descriptive research methods were made use of in the research. The study has considered 37 value stocks of 2020 (as listed in moneycontrol.com) for the analysis. The TTM P/E and YTD return of selected value stocks of 2020 was calculated to check whether all value stocks of 2020 are fundamentally good and gave positive returns. The
\end{abstract}


market prices of the stocks were collected from the BSE website. The study was hence based on Secondary data. The data was collected from March 1-December 30, 2020.

Key words: Indian equity market, Value investing, P/E Ratio, YTD, outperforming Market

Cite this Article: Chaya R and Sharada Devi K G, An Analysis of Value Stocks in Indian equity Market in 2020, International Journal of Management (IJM), 11(12), 2020, pp. 3123-3128.

http://iaeme.com/Home/issue/IJM?Volume=11\&Issue=12

\section{INTRODUCTION}

After a pandemic affected 2020, the Indian Equity market is on a high level of optimism to deliver positive returns. There is no major signal of a reversal in trend in the Indian equity market. IT and pharmaceutical companies gave good returns in 2020. The top performing BSE 500 stocks during March - December, 2020 were Tania Platforms, Adani Green Energy, Aarti Drugs, Laurus Labs, Birlasoft and Tata Communications. The worst performing BSE 500 stock was Omaxe with a negative return of -47.15 percent. (www.moneycontrol.com). It is expected that stocks with some intrinsic value and margin of safety will perform well in 2021 as well. Brokers are advising clients to buy quality value stocks as these stocks are cheap in terms of valuations.

\subsection{Value investing - A Theoretical Background}

Value Investing is the process of finding under-priced stocks, buying them, and holding them for the long-term until the market sees the value in the company. Such stocks are usually smaller companies as they have a greater potential for a large increase in their share prices. These companies usually have a relatively low price-to-earnings $(\mathrm{P} / \mathrm{E})$ ratio, below book value $(\mathrm{P} / \mathrm{B})$, or even below cash value. A good Value stock will have a long investment horizon, less risky than growth stocks and are undervalued. They have less growth potential than growth stocks and are stocks of mid to large-cap companies which pay good dividends. Value investing needs a lot of patience on the part of the investors, not to forget the opportunity one has to deal with by locking funds in value stocks.

Value stocks are available in the markets at any given point of time. One has to adopt the right process to identify stocks that are trading with some intrinsic value and showing adequate margin to safety. Often enough, value stocks are confused with low-price stocks or penny stocks. One of the practical ways to find value stocks is to first ascertain if the stocks are financially sound and that the fundamentals are attractive. Once the stocks with attractive fundamentals are identified, it will be interesting to note if the Trailing 12 Months (TTM) PE for the company is less than the industry PE or more than the industry average. But in value investing, Value trap is an illusion for investors. A value trap generally happens when investors look at the fundamentals and the market price of a stock which seems to show that the stock is valued at a discount. But in reality this is not the case as the stocks are not as cheap as they appear and actually offer little hope for growth. The illusion causes investors who are looking for a bargain to bet on such stocks, thereby taking a very risky stance wherein they believe that the stock will beat the market. However, it ends up providing either negative or unattractive returns.

\subsection{Need for the Study}

Certain segment of the Indian population continuously investing in stocks of different sectors is expecting high returns at low risk. In doing so, of late the Indian equity investors have been 
contemplating if Value Investing will serve the purpose of maximizing returns or gains on their investments. The question is how does one identify value stocks and are they available in the current buoyant market scenario? There is also a need to study if value stock investing be a marketbeating strategy.

\section{REVIEW OF LITERATURE}

The following Journal papers discuss value investing in Indian Markets.

Suresh K.Mittal and Rakesh Kumar (2014) identified the major indicators of value investing and found that price to earnings $(\mathrm{P} / \mathrm{E})$ and price to book value $(\mathrm{P} / \mathrm{B})$ are the major indicator to construct value stock portfolio. They also analysed the performance of value and growth investing and result confirmed that value stock outperformed the growth stocks globally in the long run. Indian stock market have untapped market opportunities and there is lack of research in such area. Yadav, Gopal (2014), contrasted value Stock Returns and Growth Stocks during the period of 2009 to 2013, when Indian Equity Market was in the betterment phase. This comparative study has shown that the returns from Value stocks are better than Growth stocks. Kamath Vani (2013) reported that in stock market trading, the equity investors always consider value stocks superior to growth stocks. This research paper makes an attempt to compare both the value and growth stocks for the period of five years on the basis of Earnings per Share. The study on the basis of the analysis concludes that in the long run Growth stocks give good and progressive returns compared to that of value stocks. Aswath Damodaran (2012) reported that while value investing looks impressive on paper, the performance of value investors, as a whole, is no better than that of less "sensible" investors who chose other investment philosophies and strategies. He examines explanations for why "active" value investing may not provide the promised payoffs.

\section{RESEARCH GAP}

The concept of Value Investing is known, but not explored fully in Indian context. It is necessary to explore the prospects of value investing in Indian Scenario, especially when the capital market is hit by the pandemic. In the Indian context, such analysis is not comprehensive to help the Indian investors.

\section{OBJECTIVES OF THE STUDY}

The objectives of the study were to (1) identify value stocks in 2020, (2) Calculate the P/E ratio of selected stocks and compare it with industry P/E (3) to calculate the YTD of the selected stocks.

\section{HYPOTHESIS}

The following hypothesis was framed for the study

H0: Value stocks have given positive returns during 2020 pandemic.

H1: Value stocks have not given positive returns during 2020 pandemic.

\section{RESEARCH DESIGN}

Descriptive research methods were made use of in the research. The study has considered 37 value stocks of 2020 (as listed in moneycontrol.com) for the analysis. The TTM P/E and YTD return of selected value stocks of 2020 was calculated to check whether all value stocks of 2020 are fundamentally good and gave positive returns. The market prices of the stocks were collected from the BSE website. The study was hence based on Secondary data. The data was collected from March 1 - December 30, 2020. 
$\mathrm{P} / \mathrm{E}$ ratio stands for share price dividend by Earnings per share (EPS). The TTM ratio stands for Trailing Twelve Months, which means the last 12 months of EPS are used in the calculation. YTD return is the amount of profit (or loss) realized by an investment since the first trading day of the current calendar year. YTD calculations are used by investors to compare the recent performance of a number of stocks.

Stocks with high earnings' growth rates at inexpensive valuations within a particular industry are good investments. Such stocks are value stocks. Stocks with TTM PE less than the industry average PE are considered inexpensive.

\section{ANALYSIS AND FINDINGS}

37 stocks which were available at discounted price in 2020 were considered for the study. On analysis it was confirmed that these stocks had their TTM P/E lesser than Industry P/E. Hence they could be considered as value stocks at first instance. But not all these stocks gave positive YTD or high earnings' growth.

Table 1 Calculation of P/E and YTD of selected stocks

\begin{tabular}{|c|c|c|c|c|c|}
\hline $\begin{array}{l}\text { Sr. } \\
\text { No }\end{array}$ & Name of the company & Industry & $\mathbf{P} / \mathbf{E}$ & Industry $\mathbf{P} / \mathbf{E}$ & YTD (\%) \\
\hline 1 & GE Power India & High tech industrial & 14.11 & 24.01 & -61 \\
\hline 2 & $\begin{array}{l}\text { Gujarat Mineral Development } \\
\text { Corporation }\end{array}$ & Mining & 7.3 & 13.38 & -20 \\
\hline 3 & Parag Milk Foods & Dairy & 17.33 & 75.58 & -19.72 \\
\hline 4 & KRBL Ltd & Food Processing & 9.95 & 75.58 & -13.54 \\
\hline 5 & Sobha & Real estate & 20.9 & 58.45 & -10.91 \\
\hline 6 & VST Industries & Conglomearte & 18.44 & 18.8 & -10.87 \\
\hline 7 & Welspun Corp Ltd & Textiles & 3.92 & 24.22 & -9.94 \\
\hline 8 & Bajaj Consumer care & Consumer Goods & 16.89 & 60.12 & -8.23 \\
\hline 9 & Suprajit engineering Ltd & Engineering \& Manufacturing & 29.27 & 60.22 & -5.7 \\
\hline 10 & Petronet LNG Ltd & Oil and Gas & 14.87 & 18.34 & -5.6 \\
\hline 11 & KSB & Industrial Engineering & 22.24 & 54.63 & -4.32 \\
\hline 12 & Rail Vikas Nigam & Railway infrastructure & 6.7 & 43.27 & 1.08 \\
\hline 13 & $\begin{array}{l}\text { Garden Reach Shipbuilders and } \\
\text { Engineers }\end{array}$ & Industrial Engineering & 18.94 & 43.27 & 1.26 \\
\hline 14 & PTC India & Energy & 4.83 & 12.4 & 2.2 \\
\hline 15 & Mahindra CIE Automative & Industrial Engineering & 87.66 & 7.21 & 2.4 \\
\hline 16 & $\mathrm{ACC}$ & Cement & 24.83 & 25.32 & 12.5 \\
\hline 17 & Marico Ltd & Consumer Goods & 48.67 & 60.12 & 17.49 \\
\hline 18 & Sonata Software & IT Services & 19.1 & 27.75 & 26.85 \\
\hline 19 & Varun Beverages & Food Processing & 118.27 & 201.82 & 28.15 \\
\hline 20 & KPR Mill Ltd & Textiles & 22.2 & 45.13 & 33.53 \\
\hline
\end{tabular}


Chaya R and Sharada Devi K G

\begin{tabular}{|c|l|l|c|c|c|}
\hline 21 & Alkem Laboratories Ltd & Pharmaceuticals & 22.66 & 35.31 & 39.13 \\
\hline 22 & Meghmani Organics & Chemicals & 10.15 & 50.18 & 44.16 \\
\hline 23 & HFCL & Telecommunications & 27.84 & 185.58 & 51.86 \\
\hline 24 & IRB Infrastructure Developers & Industrial Engineering & 15.68 & 43.27 & 52.51 \\
\hline 25 & FDC Ltd & Pharmaceuticals & 18.04 & 35.31 & 55.45 \\
\hline 26 & Atul Ltd & Food Processing & 32.75 & 48.54 & 58.19 \\
\hline 27 & Mphasis Ltd & IT Services & 22.82 & 27.75 & 68.94 \\
\hline 28 & Garware Technical Fibres Ltd & Industrial Engineering & 28.72 & 45.13 & 83.47 \\
\hline 29 & Ipca Laboratories Ltd & Pharmaceuticals & 26.03 & 35.31 & 90.68 \\
\hline 30 & Alembic Pharmaceuticals Ltd & Pharmaceuticals & 17.39 & 35.31 & 93.72 \\
\hline 31 & Dhanuka Agritech Ltd & Food Processing & 18.59 & 50.18 & 94.47 \\
\hline 32 & Aurobindo Pharma & Pharmaceuticals & 20.02 & 35.31 & 98.09 \\
\hline 33 & Deepak Nitrite Ltd & Chemicals & 29.93 & 48.54 & 142.7 \\
\hline 34 & Navin Fluorine International Ltd & Chemicals & 29.15 & 48.54 & 158.1 \\
\hline 35 & Granules India & Pharmaceuticals & 16.23 & 35.31 & 206 \\
\hline 36 & Alkyl Amines Chemicals Ltd & Chemicals & 32.81 & 48.54 & 252.36 \\
\hline 37 & Aarti Drugs Ltd & Pharmaceuticals & 29.07 & 35.31 & 378.22 \\
\hline
\end{tabular}

It is possible to identify several stocks where the TTM PE is less than the industry average PE. However, not all stocks that fall in this list can be good value propositions. Fundamentals need to be strong and the financials of the stocks under consideration should be healthy. It was found that all stocks under consideration had P/E values less than Industry P/E. Only 11 stocks out of 37 value stocks gave negative returns during pandemic, this is 29.7 percent of the data. 26 out of 37 stocks gave positive returns even during the pandemic hit scenario. Value stocks have given positive returns upto 378.22 percent during this period.

It is important that the investor analyses, whether value stocks really give higher earnings return in the long run.

\section{LIMITATIONS OF THE STUDY}

The study is limited to only P/E and YTD analysis of the selected stocks. Other parameters which are relevant for testing the fundamentals of the stocks could be considered for the study.

\section{CONCLUSION}

Investors have to be smart to identify value stocks and refrain from investing in any stocks that have underperformed. Value stocks may do well as there is a limit to how much money can be parked in the growth stocks. With rich valuations and sharp run up, there is little margin of safety left in the growth stocks, thus making a strong case for value stocks. Also, value stocks will tend to fall less in case we see a market correction happening.

\section{RECOMMENDATIONS}

While value stocks outperform markets in the long run, and even in pandemic situations, investors are advised to adopt a blended approach of investing where a mix of growth and value 
stocks are included in their investment portfolio. This blended approach will ensure maximizing returns of their investment portfolio, by minimizing the risk of investments in equity market

\section{REFERENCES}

[1] Damodaran, Aswath, Value Investing: Investing for Grown Ups? (April 14, 2012). Available at SSRN: https://ssrn.com/abstract=2042657 or http://dx.doi.org/10.2139/ssrn.2042657

[2] Kamath vani (2013), "Comparative Analysis of Growth Versus Value Stocks", International Journal of Science and Research.

[3] Suresh K.Mittal and Rakesh Kumar (2014) Dynamic of Equity Investment Style in Indian Stock Market: A Review Study, in Research Journal International Research Journal of Management Sociology \& Humanities, Volume 5,Issue11,Year 2014,ISSN No.2348-9359,pp225-231

[4] Yadav, Gopal, (2014), "A Comparative study of the performance of value stocks versus growth stocks during recent revival of Indian equity market "International research journal of commerce arts and science. 4,760-771.

[5] www.moneycontrol.com

[6] www.bseindia.com 